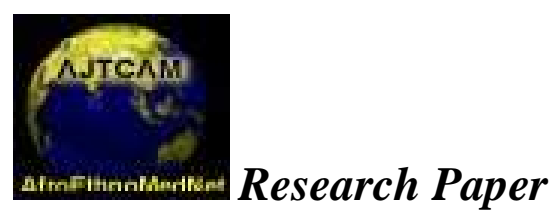

Afr. J. Infect. Diseases

www.africanethnomedicines.net

ISSN: 2006-0165@2008

\title{
SCREENING OF CRUDE EXTRACTS OF TWELVE MEDICINAL PLANTS AND "WONDER- CURE" CONCOCTION USED IN NIGERIA UNORTHODOX MEDICINE FOR ACTIVITY AGAINST MYCOBACTERIUM TUBERCULOSIS ISOLATED FROM TUBERCULOSIS PATIENTS SPUTUM
}

\author{
I. A. Adeleye*, C. C. Onubogu**, C. I. Ayolabi*, A. O. Isawumi*, and M. E. Nshiogu** \\ * Department of Botany and Microbiology, Faculty of Science,University of Lagos, Akoka Lagos \\ Nigeria ** Nigerian Institute of Medical Research (NIMR) Yaba Lagos, Nigeria \\ E-mail: adeyemi21@yahoo.com
}

\begin{abstract}
The antimicrobial activity of extracts of twelve Nigerian medicinal plant species and a "wonder cure" concoction [Epa-Ijebu]; used in traditional medicine for the treatment of tuberculosis and cough were screened for activity against Mycobacterium tuberculosis isolated from tuberculosis patient sputum and the control strains of M. tuberculosis (H37RV). Both ethanolic and aqueous solution of the extract of Allium ascalonicum, Terminalia glaucescens, Allium cepa and Securidaca longepedunculata (ethanolic extract only) at $0.05 \mathrm{~g} / \mathrm{ml}$ as well as aqueous solution of "wonder cure" concoction at same concentration inhibited the growth of $M$. tuberculosis. However at lower concentration of $0.2 \mu \mathrm{g} / \mathrm{ml}$ (critical proportion level of the control drug (isoniazide), M. tuberculosis was resistant to both aqueous and ethanolic extracts of the plants as well as the aqueous solution of the wonder-cure concoction. The phytochemical analysis of the plant extract and the EpaIjebu showed the presence of bioactive compounds: tannin, flavonoid, alkaloids, phlobatannin, anthocyanin, reducing sugar, saponin and anthraquinone. Our results offer a scientific basis for the traditional use of aqueous and ethanolic extracts of Allium ascalonicum, Terminalia glaucescens, Allium cepa, Securidaca longepeducunlata (ethanolic extract only) and aqueous solution of the "wonder cure" concoction at higher concentration against M. tuberculosis. However local herbs such as Nicotiana tabacum, Allium sativum, Aframomum melegueta, Aprus precatorius, Xylopia aethiopica, Tetrapleura tetraptera, Crinium jagus, and Garcinia kola were ineffective.
\end{abstract}

\section{Introduction}

Tuberculosis (TB) is an infectious disease, caused by the bacterium called Mycobacterium tuberculosis. It was first isolated by Robert Koch in 1882 (Ait- Khaled and Enarson, 2003). At the time, TB was rampant, causing 1/7 of all deaths in Europe and 1/3 of deaths among productive young adults (Prescott et al., 2008). Today, TB remains a problem of global importance. Among communicable diseases, TB is the second leading cause of death worldwide killing 2 million people each year (Frieden et al., 2003).

The upsurge of TB cases has been noticed in developing countries (WHO, 2003). In Nigeria, like in most other developing countries, the tuberculosis situation has worsened over the past few years. Several factors have been associated with the TB upsurge which have distinct difference in symptoms from earlier out-breaks of the disease. These include the current Human Immunodeficiency Virus (HIV) pandemic and increase in cases of drug resistant strains of TB bacilli (Onwujekwe, 2005). A prevalence of 9.2\% has been reported in one study in Nigeria and a case of fatality rate of $12 \%$ in a second study (Salami and Oluboyo, 2002; Salami and Oluboyo, 
2003). Trend from patronage of orthodox medicine to traditional medicine or a combination of both is observed in a large proportion of the population in Nigeria. This is due either to financial constraints or unavailability of manufactured drugs. Also, resistance to drugs obtained from plants is not common unlike the chemically synthesized drugs, some of which are easily metabolized by many pathogens there-by making the drugs ineffective (Ebara et al., 1990; Gangadharam et al., 1993; Akinyemi et al, 2005). There has also been a wide claim by the traditional healers about the pharmacological efficacy of their preparations and prescriptions. For instance, some traditional attendants in Western Nigeria claimed that they cured tuberculosis ('Iko efe') using some medicinal herbs and a "wonder" cure concoction called "Epa-Ijebu". The ingredients used for the preparation of the later include Citrus aurantifolia (lime) juice, Citrus aurantium (Orombo igun) and Aframomum melegueta (Ataare) fruit. Others are animal parts including snake head (various types ground into powder), whole scorpion (powdered) and poisonous rat (powdered). These recipes are mixed together in a large pot and boiled until the materials are reduced by half and then allowed to cool. The resultant product in form of paste are packed into smaller bottles and sold. The concoction is usually added to pap (a slurry of milled corn prepared in boiled water) and drunk. There is a considerable interest by scientists to identify the potentially valuable therapeutic agents contained in these plants and other remedies in order to establish the basis for their uses in folk medicinal practices. These claims need to be verified through scientific and systematic evaluation. Thus, this present study was designed to scientifically evaluate the efficacies of twelve medicinal plants and the potent wonder cure "Epa-Ijebu" used in the treatment of tuberculosis.

\section{Materials and Methods \\ Plant Materials and the wonder cure Concoction}

The plants used in this study were selected from the list of plants used by local herbalist in the preparation of various medicaments used for curing tuberculosis. Twelve plants and plant parts e.g. roots, stem, bark, leave (Table 1) were purchased from local attendants referred to as 'Elewe Omo' in various markets in Lagos State Nigeria namely Oshodi, Mushin, Epetedo, Ajegunle, and Iyana - Ipaja. They were properly identified at the Department of Botany and Microbiology University of Lagos by comparing with existing voucher samples. The plant parts such as the fruits, leaves, and stem were dried at room temperature and crushed into coarse powder by grinding in a clean mortar with pestle while barks of the plant were dried at $80^{\circ} \mathrm{c}$ for 2 days and subsequently crushed into coarse powder. Aqueous extracts and ethanol extracts were made by weighing $20 \mathrm{~g}$ of powdered plant material into the Soxhlet flask for extraction. $150 \mathrm{ml}$ of solvent was used both for alcohol and water. The apparatus was allowed to reflux for $3 \mathrm{hrs}$ and allowed to cool. The alcohol extract, was collected into clean sterile bottles and labeled accordingly. The alcohol extract was dried in the oven at $25^{\circ} \mathrm{C}$ while the aqueous extracts were freeze-dried. The plant extracts obtained were pure and ground to powder in clean mortar with pestle. They were collected in sterile universal bottles, labeled accordingly and stored in the refrigerator until required for use. The wonder cure concoction (Epa-Ijebu) was procured in prepared form from herb sellers known as 'Elewe Omo' in Mushin Market, a suburb of Lagos, Nigeria.

\section{Bacterial Susceptibility Testing}

The antibacterial activity of the plant extracts and the "wonder cure" concoction were tested on $M$. tuberculosis using proportion method (Ait-khaled and Enarson, 2003).

\section{Bacterial Culture}

The test organisms used in this study were culture isolates of Mycobacterium tuberculosis isolated from sputum of TB positive patients at Government chest clinics in Lagos metropolis. The Mycobacterium tuberculosis control strain H37RV used in the study was obtained from Nigerian Institute of Medical Research stock culture stores.

\section{Bacterial Susceptibility Testing}

The antibacterial activity of the plant extracts and 'wonder cure' concoction were tested on M. tuberculosis using indirect proportion method (Ait Klaled and Enarson,2003). This method entails using Lowestein- 
Jensen(LJ) solid medium with added amount of drug solution to give the required drug concentrations. The slants were then inoculated with standardized inoculums and compared with growth on the controls.

\section{Preparation of Culture Medium and Incorporation of Herb Extracts and the "Wonder Cure" Concoction}

Lowenstein-Jensen (LJ) medium was used for all the susceptibility testing. Each extract and the wonder cure concoction were diluted with sterile distilled water to concentrations of $0.2 \mu \mathrm{g} / \mathrm{ml}$ and $0.05 \mathrm{~g} / \mathrm{ml}$. To obtain a concentration of $0.2 \mu \mathrm{g} / \mathrm{ml}, \mathrm{g}$ of each extract/concoction was dissolved in $5 \mathrm{mls}$ of sterile distilled water and filtered through membrane filter. The filtrate was added to $45 \mathrm{mls}$ of the media in a conical flask. To obtain a concentration of $0.05 \mathrm{~g} / \mathrm{ml}, 0.75 \mathrm{~g}$ of each extract was dissolved in $15 \mathrm{mls}$ of sterile distilled water and also filtered using membrane filter. The filtrate was added to $45 \mathrm{mls}$ of the media and mixed properly. $10 \mathrm{mls}$ of each of the LJ media with extracts/concoction for the 2 concentrations were later dispensed into universal containers and slanted. Isoniazid powder at $0.2 \mu \mathrm{g} / \mathrm{ml}$ was used as the standard drug. The concentration was calculated using the formula of desired activity $(\mathrm{mg} / \mathrm{ml})=$ weight of drug) $\mathrm{x}$ potency/volume of solvents. Isoniazid potency is $1 \mathrm{~g}$ to $1 \mathrm{~g}$ substance. LJ slopes without extracts/concoction/drug were used as control medium. All the LJ slopes prepared were inspissated at $85^{\circ} \mathrm{C}$ for $45 \mathrm{mins}$, cooled and stored in a refrigerator at $4^{\circ} \mathrm{C}$ until required for use.

\section{Inoculation of slopes containing herb extracts, wonder concoction and Isoniazid}

Bacterial suspensions of Mycobacterium tuberculosis positive culture and H37RV cultures were prepared. Using a spatula, 1 to $10 \mathrm{mg}$ was taken from the primary culture and placed in a flat buttomed flask containing 12 glass beads of $3 \mathrm{~mm}$ in diameter. This was shaken for 20-30 seconds. $5 \mathrm{ml}$ of distilled water was added slowly under continuous shaking. The opacity of bacterial suspension was then adjusted by the addition of distilled water to that of McFarland 1. The 2 bacteria dilutions required for inoculation of each slope are $10^{-}$ ${ }^{3} \mathrm{mg} / \mathrm{ml}$ and $10^{-5} \mathrm{mg} / \mathrm{ml}$ of bacilli. Two slopes of medium with herb/concoction/drug and 2 slopes of medium without herb/concoction/drug were inoculated with $0.1 \mathrm{ml}$ of the 2 chosen dilutions. The inoculated slopes were loosely closed with a cap to allow for evaporation and incubated at $37^{\circ} \mathrm{C}$. The results of the sensitivity test for M.tuberculosis were read on the 28th and $42^{\text {nd }}$ day of incubation. The colonies were counted only on the slopes seeded with lowest inoculum that has produced growth. The average number of colonies obtained for the herb/concoction/drug slopes indicate the number of resistant bacilli contained in the inoculums. The ratio between the second figure and the first indicates the proportion of the resistant bacilli existing in the strain. Below are a certain proportion (the critical proportion) the strains is classified as sensitive; above, as resistant. The proportions were reported in terms of percentages.

\section{Phytochemical Screening Methods}

The screening methods were carried out using the procedure described by Harbone (1984) and Sofowora (1986). The following active constituents were tested for: - alkaloids, tannins, flavonoids, cyanogenic glycosides, anthraquinone, saponins, phylobatanins, anthrocyanosides (anthrocyanin pigment) and reducing sugar compounds.

\section{Results}

The results in Table 2 showed that at lower concentration $(0.2 \mu \mathrm{g} / \mathrm{ml})$ critical proportion level of isoniazide, M. tuberculosis was resistant to all the plant extracts and the "Epa-Ijebu". At concentration of $0.05 \mathrm{~g} / \mathrm{ml}$, extracts obtained from Allium cepa, Allium ascalonicum, Terminalia glaucescens, Securidaca longepedunculata as well as the Epa-Ijebu concoction inhibited the growth of M. tuberculosis as shown in Table 3. All the plant extracts that inhibited the growth of the culture isolates of $M$. tuberculosis also inhibited the growth of the control strains (H $37 \mathrm{RV}$ ) of M. tuberculosis H37RV (Table 4). The results also showed that $M$. tuberculosis was sensitive to the ethanolic extract of Securidaca longepedunculata but was resistant to its aqueous extracts. All the tested plants showed positive reaction to tannins, saponin, alkaloids, and anthraquinone but none possessed cyanogenic glycosides and anthocyanin pigment (Table 5). 
Table 1: Medicinal plants chosen for antimicrobial activity against Mycobacterium tuberculosis

\begin{tabular}{lll}
\hline Plant species Authorities & Family & Plant part investigat \\
& & \\
\hline Crinium jagus (Thomps.) Dandy & Amaryllidaceae & Bulb \\
Allium ascalonicum Linn. & Liliaceace & Leaves \\
Allium cepa Linn. & Liliaceae & Bulb \\
Xylopia aethiopica (Dunal) A.Rich. & Annonaceae & Fruit \\
Aprus precatorius Linn. & Papilionoide- Fabaceae & Whole plant \\
Allium sativum Linn. & Liliaceae & Fruits \\
Aframomum melegueta K. Schum & Zingiberaceae & Fruits \\
Terminalia glaucescens Planch. ex Beith. & Combretaceae & Stem \\
Tetrapleura tetraptera (Shum. et thom.) Taub. & Mimosoide- Fabaceae & Fruits \\
Garcinia kola Heckel & Clusiaceae & Fruits \\
Nicotiana tabacum Linn. & Solanaceae & Whole plant \\
Securidaca longepedinculata Fres. & Polygalaceae & Stem
\end{tabular}

\section{Discussion}

This present study revealed that four of the plant extracts (Allium cepa, Allium ascalonicum, Terminalia glaucescens, Securidaca longepedunculata) as well as the wonder cure concoction showed activity on both the test organism and the control strain. Adjanohun et al. (1991) and Adeleye and Opia (2003), had earlier reported the efficacy of Allium cepa and Allium ascalonicum as cough remedies. Also Akinyemi et al reported the antimicrobial property of Terminalia avicenoides on methicillin resistant Staphylococcus aureus. The activity of the wonder cure concoction [ Epa - Ijebu] may be due to its acid nature (it has a low $\mathrm{pH}$ ).

It is worthy of note that eight other plant extract screened including Nicotiana tabacum did not show activity against M. tuberculosis. Previous study (Adeleye and Opia,2003) has shown that N. tabacum had no antibacterial effect on organism causing upper respiratory tract infections. Although the traditional use of Crimium jagus, Xylopia aethiopica ,Aprus precatorius, Allium sativum, Aframomum melegueta and Tetrapteura tetraptera as cough remedy had been well documented (Adjanohoun et al., 1991). Our study showed that they did not inhibit $M$. tuberculosis in vitro.

The phytochemical analysis of the plant extracts showed the presence of biologically active constituents such as alkaloid, tannins, flavonoids, anthraquinones, saponins, phlobatannins and reducing sugar compounds but none posses cyanogenic glycosides and anthrocyanin pigment. Elsewhere in Democratic Republic of Congo similar observations have been made in plants employed for traditional medicines, which were known to contain the above mentioned bioactive components (Otshudi et al., 2000).

Our findings may provide the rational for the traditional use of both water and ethanol extracts of Allium ascalonoicum, Terminalia glaucescens, Allium cepa and Securidaca longepedunculata as well as aqueous solution of wonder cure concoction "Epa - Ijebu" for therapeutic cure of tuberculosis. The antimicrobial activities could be enhanced if the active components are purified and adequate dosage determined for proper administration.

\section{Acknowledgement}

We are grateful to the management of the Nigerian Institute of Medical Research Yaba Lagos for allowing us to use their facilities. Thanks are also due to Mr.E.O.Omonigbehin for his technical assistance. 
Table 2: Critical proportion calculations using isoniazide as the standard at lower concentration of herb extracts $(0.2 \mu \mathrm{g} / \mathrm{ml})$

\begin{tabular}{|c|c|c|c|c|c|c|c|c|c|}
\hline $\begin{array}{l}\text { Name of Extract/ } \\
\text { Concoction }\end{array}$ & Solvent & $\begin{array}{l}\text { (1)Control } \\
10^{-3}\end{array}$ & $\begin{array}{l}\text { (2) Herb } \\
\text { Extract } 10^{-5}\end{array}$ & $\begin{array}{l}\text { B } \\
(1 \div 2)\end{array}$ & $\begin{array}{l}\text { (3)Control } \\
10^{-5}\end{array}$ & $\begin{array}{l}\text { (4) Herb } \\
\text { Extract } 10^{-3}\end{array}$ & $\begin{array}{l}\mathrm{A} \\
(3 \div 4)\end{array}$ & $\begin{array}{l}\text { Critical } \\
\text { proportion } \\
\text { B:A\% }\end{array}$ & Sensitivity \\
\hline \multirow{2}{*}{ Crinum jagus } & Water & 100 & 100 & 1 & 100 & 100 & 1 & $\geq 1$ & Resistant \\
\hline & ethanol & 100 & 100 & 1 & 100 & 100 & 1 & $\geq 1$ & Resistant \\
\hline \multirow{2}{*}{ Allium cepa } & Water & 100 & 100 & 1 & 100 & 50 & 2 & $\geq 2$ & Resistant \\
\hline & Ethanol & 100 & 100 & 1 & 100 & 40 & 2.5 & $\geq 2.5$ & Resistant \\
\hline \multirow[t]{2}{*}{ Xylopia aethiopica } & Water & 100 & 100 & 1 & 100 & 100 & 1 & $\geq 1$ & Resistant \\
\hline & Ethanol & 100 & 100 & 1 & 100 & 100 & 1 & $\geq 1$ & Resistant \\
\hline \multirow[t]{2}{*}{ Abrus precatorius } & Water & 100 & 100 & 1 & 100 & 100 & 1 & $\geq 1$ & Resistant \\
\hline & Ethanol & 100 & 100 & 1 & 100 & 100 & 1 & $\geq 1$ & Resistant \\
\hline \multirow[t]{2}{*}{ Allium ascalonicum } & Water & 100 & 100 & 1 & 100 & 80 & 1.25 & $\geq 1.25$ & Resistant \\
\hline & Ethanol & 100 & 100 & 1 & 100 & 50 & 2 & $\geq 2$ & Resistant \\
\hline \multirow[t]{2}{*}{ Allium Sativum } & Water & 100 & 100 & 1 & 100 & 100 & 1 & $\geq 1$ & Resistant \\
\hline & Ethanol & 100 & 100 & 1 & 100 & 100 & 1 & $\geq 1$ & Resistant \\
\hline \multirow[t]{2}{*}{ Aframoтит melegueta } & Water & 100 & 100 & 1 & 100 & 100 & 1 & $\geq 1$ & Resistant \\
\hline & Ethanol & 100 & 100 & 1 & 100 & 100 & 1 & $\geq 1$ & Resistant \\
\hline \multirow[t]{2}{*}{ Terminalia glaucescens } & Water & 100 & 50 & 2 & 100 & 20 & 5 & $\geq 5$ & Resistant \\
\hline & Ethanol & 100 & 80 & 1.25 & 100 & 50 & 2 & $\geq 2$ & Resistant \\
\hline \multirow[t]{2}{*}{ Tetrapleura tetraptera } & Water & 100 & 100 & 1 & 100 & 100 & 1 & $\geq 1$ & Resistant \\
\hline & Ethanol & 100 & 100 & 1 & 100 & 100 & 1 & $\geq 1$ & Resistant \\
\hline \multirow[t]{2}{*}{ Grarcinig kola } & Water & 100 & 100 & 1 & 100 & 100 & 1 & $\geq 1$ & Resistant \\
\hline & Ethanol & 100 & 100 & 1 & 100 & 100 & 1 & $\geq 1$ & Resistant \\
\hline \multirow[t]{2}{*}{ Nicotina tabacum } & Water & 100 & 100 & 1 & 100 & 100 & 1 & $\geq 1$ & Resistant \\
\hline & Ethanol & 100 & 100 & 1 & 100 & 100 & 1 & $\geq 1$ & Resistant \\
\hline Securidaca & Water & 100 & 100 & 1 & 100 & 50 & 2 & $\geq 2$ & Resistant \\
\hline longepedunculata & Ethanol & 100 & 100 & 1 & 100 & 50 & 2 & $\geq 2$ & Resistant \\
\hline \multirow[t]{2}{*}{ Salt } & Water & 100 & 100 & 1 & 100 & 100 & 1 & $\geq 1$ & Resistant \\
\hline & Ethanol & 100 & 100 & 1 & 100 & 100 & 1 & $\geq 1$ & Resistant \\
\hline \multirow[t]{2}{*}{ Epa- Ijebu } & Water & 100 & 100 & 1 & 100 & 50 & 2 & $\geq 1$ & Resistant \\
\hline & Ethanol & 100 & 100 & 1 & 100 & 80 & 1.25 & $\geq 1.25$ & Resistant \\
\hline Isoniazide & Water & 100 & 0 & 0 & 100 & 0 & 0 & $\leq 1$ & Sensitive \\
\hline
\end{tabular}


Table 3: Critical proportion calculations using isoniazide as the standard at higher concentration of herb extracts $(0.05 \mathrm{~g} / \mathrm{ml})$

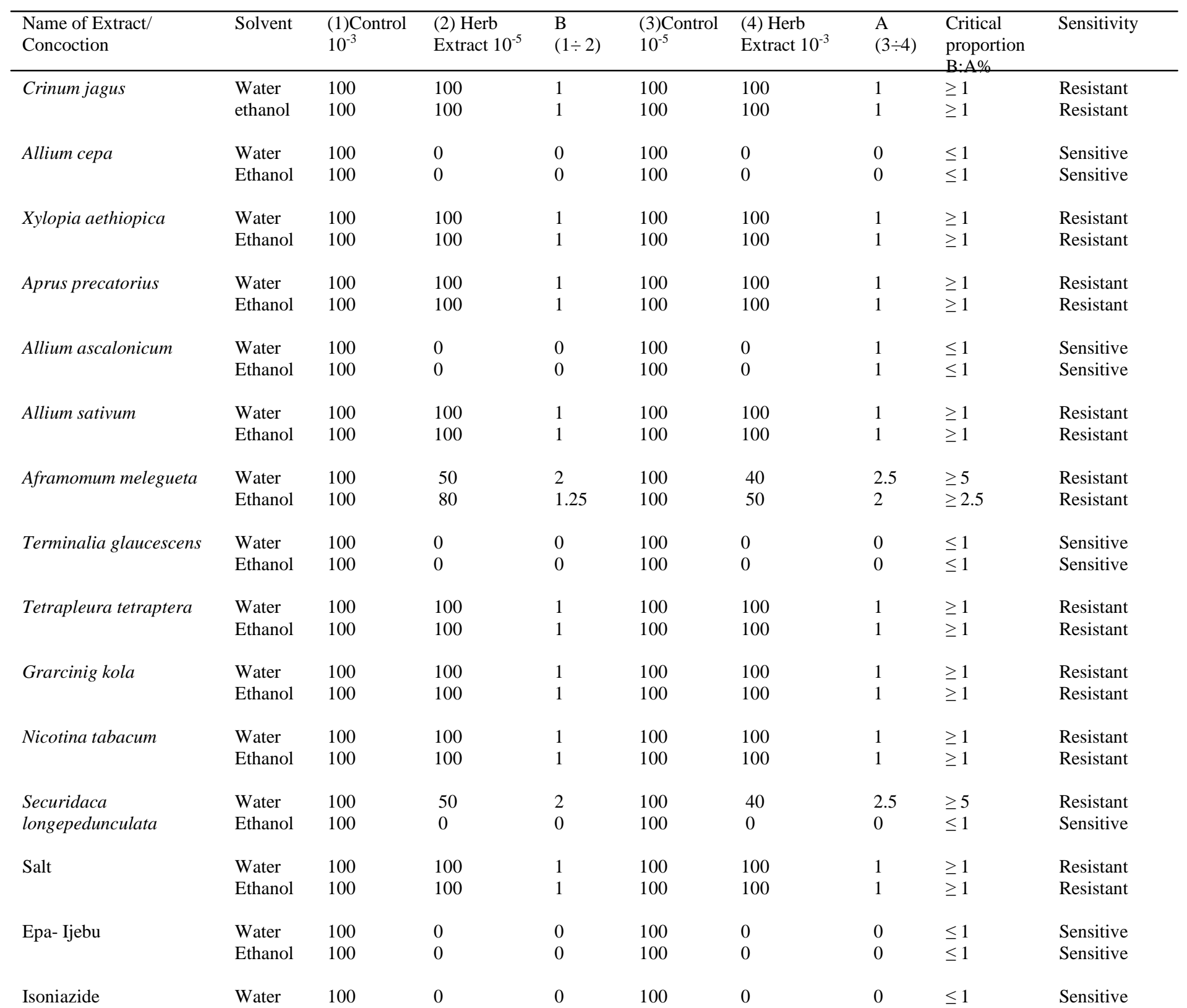


Adeleye et al., Afr. J. Infect. Dis. 2(2): 85 - 93

Table 4 : Critical proportion calculations using isoniazide as the standard at higher concentration of herb extracts $(0.05 \mathrm{~g} / \mathrm{ml})$

\begin{tabular}{|c|c|c|c|c|c|c|c|c|c|}
\hline $\begin{array}{l}\text { Name of Extract/ } \\
\text { Concoction }\end{array}$ & Solvent & $\begin{array}{l}\text { (1) } \\
\text { Control } \\
10^{-3} \\
\end{array}$ & $\begin{array}{l}\text { (2) Herb } \\
\text { Extract } 10^{-5}\end{array}$ & $\begin{array}{l}\text { B } \\
(1 \div 2)\end{array}$ & $\begin{array}{l}\text { (3) } \\
\text { Control } \\
10^{-5} \\
\end{array}$ & $\begin{array}{l}\text { (4) Herb } \\
\text { Extract } 10^{-3}\end{array}$ & $\begin{array}{l}\text { A } \\
(3 \div 4)\end{array}$ & $\begin{array}{l}\text { Critical } \\
\text { proportion } \\
\mathrm{B}: \mathrm{A} \%\end{array}$ & $\begin{array}{l}\text { Sensitivity of } \\
\text { M.tuberculosis } \\
(\mathrm{H} 37 \mathrm{RV})\end{array}$ \\
\hline \multirow[t]{2}{*}{ Allium сера } & Water & 100 & 0 & 0 & 100 & 0 & 0 & $\leq 1$ & Sensitive \\
\hline & Ethanol & 100 & 0 & 0 & 100 & 0 & 0 & $\leq 1$ & Sensitive \\
\hline \multirow[t]{2}{*}{ Allium ascalonicum } & Water & 100 & 0 & 0 & 100 & 0 & 0 & $\leq 1$ & Sensitive \\
\hline & Ethanol & 100 & 0 & 0 & 100 & 0 & 0 & $\leq 1$ & Sensitive \\
\hline \multirow[t]{2}{*}{ Terminalia glaucescens } & Water & 100 & 100 & 0 & 100 & 100 & 0 & $\leq 1$ & Sensitive \\
\hline & Ethanol & 100 & 100 & 0 & 100 & 100 & 0 & $\leq 1$ & Sensitive \\
\hline \multirow{3}{*}{$\begin{array}{l}\text { Securidaca } \\
\text { longepedunculata }\end{array}$} & & & & & & & & & \\
\hline & Water & 100 & 0 & 0 & 100 & 0 & 0 & $\leq 1$ & Sensitive \\
\hline & Ethanol & 100 & 0 & 0 & 100 & 0 & 0 & $\leq 1$ & Sensitive \\
\hline \multirow{2}{*}{ Epa-Ijebu } & Water & 100 & 0 & 0 & 100 & 0 & 0 & $\leq 1$ & Sensitive \\
\hline & Ethanol & 100 & 0 & 0 & 100 & 0 & 0 & $\leq 1$ & Sensitive \\
\hline Isoniazide & Water & 100 & 100 & 0 & 100 & 100 & 0 & $\leq 1$ & Sensitive \\
\hline
\end{tabular}


Table 5: Phytochemical Analysis of Plant Extracts and Epa-Ijebu

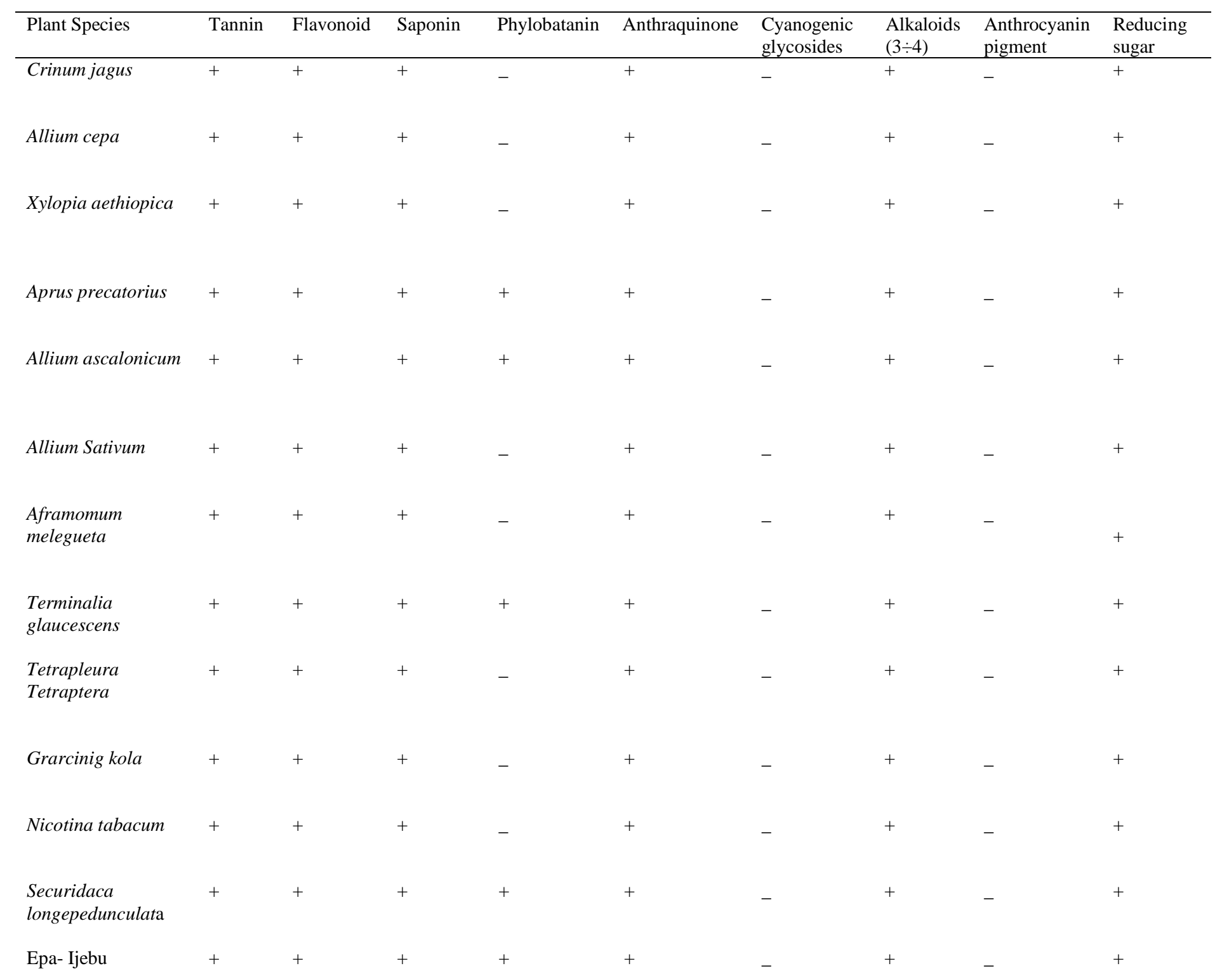




\section{References}

1. Adeleye, I. A. and Opia, L. (2003). Antimicrobial activity of extract of Local cough mixtures on upper respiratory tract pathogens. West indies Med. J. 52 (3): $188-190$

2. Adjanohoun, E., Ahiyi, M.R.A., Ake, Assi L., Dramane, K., Elewude, J. A, Fadoju, S.O., Gbile, Z.O, Goudote, E, Johnson, C.L.A and Keita, A. (1991). Traditional Medicine and Pharmacopoeia: Contribution to ethnobotanical and floristic studies in Western Nigeria. Scientific, Technical and Research Commission of the Organization of African Unity (O.A.U/S.T.R.C) 19 - 303.

3. Ait-Khaled, N. and Enarson, D. A. (2003). Tuberculosis: A manual for medical students??. World Health Organization. Geneva 2003; 1: 1 -20

4. Akinyemi, K.O., Oladapo, O., Okwara, C.E., Ibe, C.C. and Fasure, K.A. (2005). Screening of crude extracts of six medicinal plants used in South - West Nigerian unorthodox medicine for antimethicillin resistant Staphylococcus aureus activity. BMC Complementary Alternative Med. 5:6

5. Ebara, R.V.B., Madunagu, E.U. and Otung, I. N. (1990). Microbiological exploitation of Cardiac Glycosides and Alkaloids from Garcinia kola and Borreria ocymoides. J. Bacteriol 871: 398 - 401.

6. Frieden, T.R., Sterling, T.R., Munsiff, S.S., Watt, C.J. and Dye, C. (2003). Tuberculosis Lancet 362: $97-889$.

7. Gangadharam, P.R.J., Reichmann, L. B. and Hershfield, E. S. (1993). Drug resistance in tuberculosis. In a Comprehensive International Approach $1^{\text {st }}$ edition New York. Marcel Deker $293-$ 328

8. Harbone, J. B. (1984). Phytochemical Methods. In: A guide to modern techniques of plant analysis. Fakenhan Press, Britain 162 - 167.

9. Onwujekwe, D. (2005). National Tuberculosis Reference Laboratory. Microbiology Division. Nigerian Institute of Medica Research, Yaba, Lagos Nimr News 2005, 4(1):6

10. Otshudi, A. L, Foriers, A., Vercryise, A., VanZeebrockect, A. and Lawwers, S. (2000). In vitro antibacterial activities of six medicinal plants traditionally used for the treatment of dysentery and diarrhea in Democratic Republic of Congo (DRC), Phytomedicine 7(2):167- 172.

11. Prescott, Harley. and Klein's Microbiology,(2008). Human diseases caused by bacteria. Edited by Willey J.M, Sherwood, L.M and Woolverton, J.C , Mc Graw Hill U.S.A. 2008: 747 - 745

12. Salami, A.K. and Oluboyo, P. O. (2002). Hospital Prevalence of Pulmonary tuberculosis and coinfection with Human Immuno deficiency Virus in Ilorin; A review of nine years (1991 - 1999) West Afr. J. Med. 4:24 - 27

13. Salami, A.K. and Oluboyo, P.O. (2003). Management out come of pulmonary tuberculosis, a nine year review in Ilorin. West Afr.J. Med. 22: $144-119$.

14. Sofowora, A. (1986). Retrospect and Prospects. In: The state of medical plants Research in Nigeria.University of Ife press, Ile - Ife Nigeria $1-10$.

15. WHO (2003). Treament of Tuberculosis in guidelines for National Programmes. Third Edition 20, Avenue Appia Ch 1211 Geneva 27, Switzerland 2003, 39 - 60 